\title{
ISLAND MYOCUTANEOUS MEDIAL GASTROCNEMIUS FLAP IN THE RECONSTRUCTION OF KNEE AND PROXIMAL LOWER LEG DEFECTS
}

\author{
Dejan Vulovic \\ Center for Plastic Surgery, Clinical center "Kragujevac", Kragujevac, Serbia \\ Department for Surgery, Faculty of Medical Sciences, University of Kragujevac, Kragujevac, Serbia
}

\section{OSTRVASTI MIOKUTANI MEDIJALNI GASTROKNEMIJUS REŽANJ U REKONSTRUKCIJI KOLENA I PROKSIMALNOG DELA POTKOLENICE}

\author{
Dejan Vulović \\ Centar za plastičnu hirurgiju, Klinički centar "Kragujevac", Kragujevac \\ Katedra za hirurgiju, Fakultet medicinskih nauka Univerziteta u Kragujevcu
}

\section{ABSTRACT}

Skin defects with bare bones, cartilage and ligaments in the knee region are a significant surgical problem. The aim of this study is to present a reconstruction of the compound skin and soft tissue defects at the knee region with an island arterial medial myocutaneous gastrocnemius flap.

\section{INTRODUCTION}

Skin defects are a significant reconstructive problem, especially when they are extensive and associated with deperiosted bone or cartilaginous structures $(1,2)$. In these situations, covering of the defect must be done with well vascularized tissue, such as a flap. The most complicated cases of that kind are on the lower leg, primary due to the specific anatomy of the soft tissues and vascularization (37). When the defects of the skin and soft tissues involve the joint region, the situation is even more complex, because of the later function. Open bone fractures with skin defects are a significant problem especially in the case of comminuted fractures and if the defect is large and deep. Skin defects in the knee region are usually of a traumatic etiology. Reconstruction in these conditions must insure coverage with good quality soft tissues to avoid skin contracture. There are numerous methods with

\section{SAŽETAK}

Defekti kože u kojuma su eksponirane deperiostirane kosti, hrskavice lišene perihondrijuma ili tetive bez paratenona značajan su hirurški problem. Cilj ovog saopštenja jeste da se prikaže rekonstrukcija kompleksnog defekta kože i mekih tkiva $u$ regiji kolena primenom ostrvastog arterijalnog medijalnog mišićno-kožnog gastroknemijus režnja.

different kinds of flaps (8-10). For this reason the aim of this study was to present a case of complex posttraumatic defects in the knee region and proximal part of the lower leg, and the choice of the reconstruction method.

\section{CASE REPORT}

A man, aged 56 years, had an injury of the knee region and proximal part of the right lower leg. A comminuted fracture of the tibia was present with skin avulsion and primary defect of the skin and underlying tissues. (Picture 1.A,B). There were no other injuries, and the neurocirculatory status distal to the wound was normal. Immediately, at the same day, primary surgical treatment and external fixation was performed by the orthopedic surgeon. On the fifth postoperative day, the second

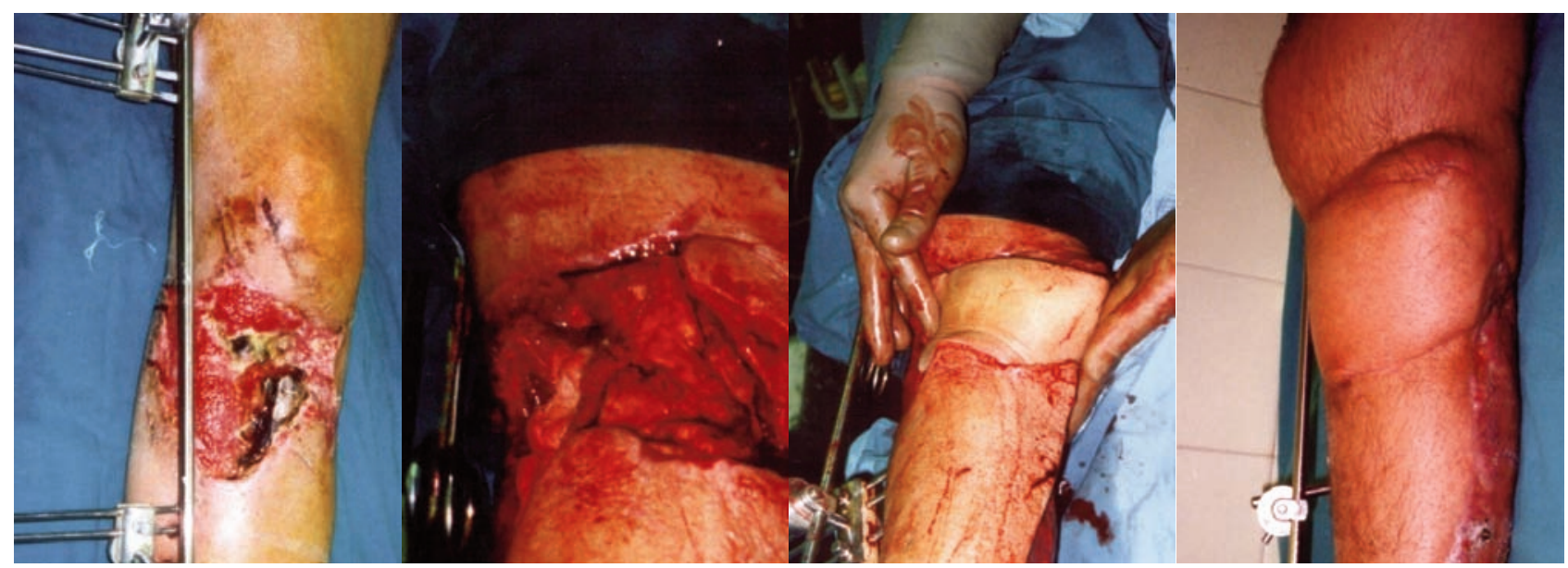

Picture 1. Complex soft tissue defect in the knee region and lower leg after mutilating injury, with exposed deep structures, and reconstruction with the island medial gastrocnemius flap. (Dr Vulović, KBC Kragujevac 2000.god.). 
surgery was performed by a plastic surgeon, when the defect was closed with an island arterial medial gastrocnemius myocutaneous flap. Under tourniquet control, the medial sural artery and veins were dissected and according to the shape and size of the defect, the island myocutaneus flap was elevated with base of a vascular bundle, and moved in to the recipient area. (Picture 1.C) The arc of the rotation was wide enough, without tension at the vascular pedicle. The wound was sutured in anatomic layers without tension. Secondary defect of the flap was covered with a split thickness skin autograft. The postoperative course was regular (Picture 1.D) and the patient was referred to intensive physical therapy that has resulted in a satisfactory range of motion in the knee joint.

\section{DISCUSSION}

Soft tissue defects at the pretibial and knee region can be primary or secondary after injury, the excision of the tumors, inflammation or the dehiscence of the surgical wound. Such defects usually could not be closed by direct approximation of the wound edges without tension or leaving a cavum inside, so it is necessary to apply plastic surgery methods. Even a small defect in the pretibial area generally needs flap coverage.

The first detailed examination of the muscle vascularization was reported by Mathes in 1979, and he clasified them into four groups (11). The idea that skeletal muscle vessels are important for skin vascularization, was not completely understood until McCrow and Dibbel (1977) had published their results after detailed investigations of vascularizations of myocutaneous flaps. After their work, many myocutaneous flaps became a standard method of reconstruction $(12,13)$. Among the first was the medial gastrocnemius myocutaneous flap.

The main goal in plastic surgery is rapid and optimal restauration of function and form. In the planning and choice of the reconstructive method, this classification of the defects is useful: 1. Skin defect and superficial soft tissue; 2. Skin defects and soft tissue with exposed deeper structures; 3. Skin defects, soft tissues, tendons and nervs; 4. Skin defects, soft tissues and bone fracture; 5. Skin defects, soft tissues and defect of the bone; 6 . Defects of the skin, soft tissue, tendons, nervs and bone.

The medial head of gastrocnemius muscle can be used as a flap in various types: island myocutaneous arterial flap, muscle flap with skin graft, distaly based flap, bipedicular flap, cross-leg flap and a free flap (14-17).

The capabilities and advantages of the presented method, may be numerous:

- One-stage surgery;
- Suitable vascularization with a constant and one vascular pedicle of adequate length and diameter;

- Covering the defect with well vascularized tissue such as skeletal muscle, which is of importance for the sanation of bone structure;

- Relative easy flap dissection;

- Possibility of usage of muscle only as a flap, with skin graft, which provides thinner tissue cover;

- Functional deficit in the donor region is not very significant;

The main disadvantages of the medial gastrocnemius myocutaneous flap is its thickness and aesthetic appearance of the skin graft at the donor area.

\section{REFERENCES}

1. Ger R. The management of pretibial skin loss. Surgery 1968, 63:757-63.

2. Ger R. The management of open fractures of the tibia with skin loss. J Trauma 1971, 2:6-10.

3. Heartsch PA. The blood supply of the skin of the leg: a post mortem investigation. Br J Plast Surg 1981, 31: 470-7.

4. Stadler F, Brenner E, Todoroff B, et al. Anatomical study of the perforating vessels of the lower leg. Anat Rec 1999; 255:374-9.

5. Vulović Dejan. Morfologija i vaskularizacija medijalne glave musculus gastrocnemius-a. Magistarska teza. Medicinski fakultet. Kragujevac, 1998.

6. Vulović D, Novaković B. Dopler ultrasonografija u plastičnoj hirurgiji. Novaković B. Vaskularna dopler ultrasonografija. Srpska Akademija nauka i umetnosti. Kragujevac. 1999.

7. Vulović D, Novaković B, Vulović T. Dopler detekcija septokutanih perforantnih krvnih sudova u planiranju fasciokutanih i fascioadipoznih režnjeva na potkolenici. Novine u vaskularnoj hirurgiji i angiologiji. SANU, Kragujevac, Liceum, 2001.

8. Jordan DJ, Malahias M, Hindocha S, Juma A. Flap decisions and options in soft tissue coverage of the lower limb. Open Orthop J 2014; 31:423-32.

9. Gravvanis A, Kyriakopoulos A, Kateros K, Tsoutsos D. Flap reconstruction of the knee: A review of current concepts and a proposed algorithm. World J Orthop 2014; 5:603-13.

10. Shen Y, Ma C, Hu X, Wang C, Zhang C.Tissue flap repair strategy for severe defects of skin and soft tissue around the knee joints. Zhonghua Shao Shang Za Zhi 2015; 31:331-6. 
11. Mathes SJ, Nahai F. Classification of the vascular anatomy of muscles: experimental and clinical correlation. Plast Reconstr Surg 1981; 67:177-87.

12. Feldman JJ, Cohen BE, May JW Jr. The medial gastrocnemius myocutaneous flap. Plast Reconstr Surg 1978; 61:531-9.

13. Dibbell DG, Edstrom LE.The gastrocnemius myocutaneous flap. Clin Plast Surg 1980; 7:45-50.

14. El-Sherbiny M. Pedicled gastrocnemius flap: clinical application in limb sparing surgical resection of sarcoma around the knee region and popliteal fossa. J Egypt Natl Canc Inst 2008; 20:196-207.
15. Veber M, Vaz G, Braye F, et al. Anatomical study of the medial gastrocnemius muscle flap: a quantitative assessment of the arc of rotation. Plast Reconstr Surg 2011; 128:181-7.

16. Tetreault W, Della Valle J, Bohl D, Lodha J, Biswas D, Wysocki RW. What factors influence the success of medial gastrocnemius flaps in the treatment of infected TKAs? Clin Orthop Relat Res 2016; 474:752-63.

17. Tosun B, Selek O, Gok U, Tosun O. Medial gastrocnemius muscle flap for the reconstruction of unhealed amputation stumps. J Wound Care 2017; 26:504-7. 